Zbigniew Korzeb*

\title{
AKTYWNOŚĆ INWESTORÓW W PROCESACH FUZJI I PRZEJĘĆ BANKÓW KOMERCYJNYCH W POLSKIM SEKTORZE BANKOWYM
}

\section{Wprowadzenie}

Zagadnienie aktywności inwestorów na rynku fuzji i przejęć należy do tematów najczęściej poruszanych w badaniach naukowych. Pomimo licznych opracowań na ten temat brak jest jednoznacznych ustaleń wyjaśniających przyczynę tego zjawiska. Celem niniejszego opracowania jest analiza cykliczności fuzji i przejęć banków komercyjnych w polskim sektorze bankowym. Badaniami objęto zachowanie inwestorów strategicznych, dokonujących takich przedsięwzięć inwestycyjnych po 1989 r.

\section{Przegląd literatury}

Wytłumaczenie zjawiska fal wzmożonej aktywności na rynku fuzji i przejęć R.A. Brealey, S.C. Myers i F. Allen zaliczyli do dziesięciu najbardziej kontrowersyjnych problemów, które nie zostały dotychczas jednoznacznie rozstrzygnięte w teorii współczesnych finansów ${ }^{1}$. Autorzy ci akcentują, iż o ile możliwe jest wyjaśnienie powodów zaistnienia pojedynczych transakcji, o tyle do chwili obecnej nie postawiono ogólnej hipotezy uzasadniającej obserwowaną arytmię zachowania inwestorów.

Przedmiotowe badania prowadzone w ostatnich latach sugerują, że aktywność na rynku fuzji i przejęć jest skorelowana przede wszystkim z nieadekwatną wyceną akcji na rynku kapitałowym, która nie odzwierciedla rzeczywistej wartości spółek

* Politechnika Białostocka, Wydział Zarządzania.

1 R.A. Brealey, S.C. Myers, F. Allen, Principles of Corporate Finance, Ninth Edition, McGraw-Hill, New York 2008, s. 975. 
(w pewnych okresach akcje są niedowartościowane lub przewartościowane) $)^{2}$. Apogeum transakcji przypada na okres, gdy na rynku znajduje się grupa spółek mogących stać się obiektem przejęcia, a których wariancja stopy zwrotu $\mathrm{z}$ akcji jest niedoszacowana przez rynek. Ekonomiści zauważają także, iż podobna sytuacja może zachodzić w wypadku przeszacowania akcji spółek, będących potencjalnymi nabywcami. Ich zarządy będą bowiem dążyć do wykorzystania zaistniałej dywergencji poprzez złożenie ofert zakupu innych firm, proponując, aby formą płatności były przewartościowane własne akcje.

V. Maksimovic, G. Phillips i L. Yamg, analizując zagadnienie w kontekście formy własności potencjalnych inwestorów, wskazują, że głównym czynnikiem decydującym o skali podejmowanych fuzji i przejęć jest kapitalizacja rynkowa spółek oraz koszt finansowania zewnętrznego ${ }^{3}$.

Do podobnych wniosków dochodzą B. Jovanovic i P. Roussseau, formułując hipotezę, w której czynnikiem decydującym o skali procesów konsolidacyjnych jest zaistnienie na rynku dychotomii, determinowanej poziomem współczynnika q-Tobina w poszczególnych spółkach (spółki o wysokim wskaźniku q-Tobina nabywają akcje spółek o niskim wskaźniku) ${ }^{4}$. Nieefektywność informacyjna służy także jako wytłumaczenie fali połączeń w koncepcji E. Morellca i A. Zhdanova ${ }^{5}$, którzy w swoim modelu wykorzystali analogie między rynkiem transakcji fuzji i przejęć oraz rynkiem opcji.

A. Shleifer i R.W. Vishny także zauważają występowanie nieprawidłowości w wycenie walorów na giełdzie papierów wartościowych. W próbie wyjaśnienia rozkładu liczby transakcji w poszczególnych latach autorzy ci kładą jednak nacisk na aktywną rolę menedżerów, doskonale orientujących się w rzeczywistej wartości spółek uczestniczących w połączeniu, upatrując przyczyn nieprawidłowości w aspektach behawioralnych i nieracjonalności inwestorów ${ }^{6}$.

2 V. Maksimovic, G. Phillips, The Market for Corporate Assets: Who Engages in Mergers and Asset Sales and Are There Efficiency Gains?, "Journal of Finance" 2001, No. 56(6), s. 2019-2065; M. Rhodes-Kropf, S. Viswanathan, Market Valuation and Mergers Waves, "Journal of Finance" 2004, No. 59(6), s. 2685-2718; M. Rhodes-Kropf, D.T. Robinson, S. Viswanathan, Valuation Waves and Merger Activity. The Empirical Evidence, "Journal of Financial Economics" 2005, No. 77(3), s. 561-603; M. Dong, D. Hirshleifer, S. Richardson, S.H. Teoh, Does Investor Misvaluation Drive the Takeover Market?, "Journal of Finance" 2006, No. 61(2), s. $725-762$.

3 V. Maksimovic, G. Phillips, L. Yang, Private and Public Merger Waves, "Journal of Finance" 2013, No. 68(5).

4 B. Jovanovic, P. Rousseau, The Q-theory of Mergers, "American Economic Review" 2002, No. 92(2), s. $198-204$

5 E. Morellec, A. Zhdanov, The Dynamics of Mergers and Acquisitions, "Journal of Financial Economics" 2005, No. 77(3), s. 649-672.

6 A. Shleifer, R.W. Vishny, Stock Market Driven Acquisitions, "Journal of Financial Economics" 2003, No. 70(3), s. 295-311. 
Wzrost aktywności inwestorów na rynku fuzji i przejęć jest także tłumaczony zmianami w otoczeniu spółek: szokowymi przeobrażeniami zachodzącymi w dynamicznie rozwijających się branżach gospodarki ${ }^{7}$, tendencjami do deregulacji i liberalizacji rynku ${ }^{8}$ oraz występującymi barierami wejścia do sektora ${ }^{9}$. J. Harford uściśla, że zmieniające się warunki ekonomiczne wpływają na poziom środków znajdujących się w dyspozycji potencjalnych nabywców oraz możliwość pozyskania dodatkowego kapitału na rynkach finansowych ${ }^{10}$. Argumentuje on, iż wielkość nakładów inwestycyjnych, niezbędnych do zrealizowania transakcji, jest uzależniona między innymi od kosztów transakcyjnych ponoszonych w tego typu przedsięwzięciach w określonym momencie. Harford upatruje zwiększenia liczby fuzji i przejęć we wzroście gospodarczym. Argumentuje on, iż w okresie ożywienia gospodarki inwestorzy mają łatwiejszy dostęp do zewnętrznego finansowania oraz niższe koszty pozyskania wymaganego kapitału.

\section{Dobór próby}

Jednym $\mathrm{z}$ najważniejszych problemów związanych $\mathrm{z}$ dokonaniem analizy jest także ustalenie liczby transakcji zrealizowanych w polskim systemie bankowym oraz uściślenie momentu, w którym nastąpiło połączenie lub przejęcie banku. Podstawową trudnością związaną ze szczegółowym skwantyfikowaniem liczby fuzji i przejęć w polskim sektorze bankowym, a przede wszystkim ustaleniem okresu, w którym one nastąpiły, jest paradoksalnie problem z identyfikacją terminu, od kiedy inwestor strategiczny nabywał możliwość kierowania polityką operacyjną, finansową i inwestycyjną przejmowanego lub łączonego banku. Wątpliwości nie budzą sytuacje, w których główny akcjonariusz spełniał warunki jednostki dominującej w rozumieniu ustawy o rachunkowości. Kwestią wymagającą rozwiązania jest natomiast rozstrzygnięcie pozostałych przypadków, czy uzyskanie statusu znaczącego inwestora (w świetle tej samej ustawy) upoważnia do stwierdzenia, że nastąpiło przejęcie banku oraz określenie kryteriów wyznaczenia momentu, kiedy to nastąpiło.

7 G. Andrade, E. Stafford, Investigating the Economic Role of Mergers, "Journal of Corporate Finance" 2004, No. 10(1), s. 1-36; G. Andrade, M. Mitchell, E. Stafford, New Evidence and Perspectives on Mergers, "Journal of Economic Perspectives" 2001, No. 15(2), s. 103-120.

8 J. Hagendorff, M. Collins, K. Keasey, Bank Deregulation and Acquisitions Activity: Cases of the US, Italy and Germany, "Journal of Financial Regulation and Compliance" 2007, No. 15(2), s. 199-209.

9 A.N. Berger, S.D. Bonime, L.G. Goldberg, L.J. White, The Dynamics of Market Entry: The Effects of Mergers and Acquisitions on Entry in the Banking Industry, "Journal of Business" 2004, No. 77(4), s. 797-834.

10 J. Harford, What Driver Merger Waves?, "Journal of Financial Economics” 2005, No. 77(3), s. 529-560. 
Analiza ex-post dotychczasowych procesów konsolidacyjnych w polskim sektorze bankowym unaocznia, iż nie można dokonywać jednoznacznych konstatacji, opierając się na ustawowej terminologii. Dlatego też w pracy zastosowano kryterium podmiotowe, rozpatrując poszczególne przypadki w indywidualny sposób poprzez skoncentrowanie się na ostatecznym rezultacie fuzji lub przejęcia. Dzięki takiemu podejściu uniknięto problemów związanych z podziałem dychotomicznym wszystkich transakcji z udziałem banków komercyjnych. Analizą objęto wszystkie transakcje przeprowadzone po $1989 \mathrm{r}$.

Pierwsza transakcja przejęcia banku komercyjnego miała miejsce w $1992 \mathrm{r}$. W podanym wykazie utworzenie Grupy Pekao SA potraktowano jako trzy oddzielne fuzje. W ostatecznej klasyfikacji wyodrębniono 122 transakcje fuzji i przejęć, które zostały przeprowadzone do końca 2014 r. (tabela 1).

Tabela 1. Liczba fuzji i przejęć w sektorze banków komercyjnych w Polsce w latach 1992-2014

\begin{tabular}{|l|c|c|c|c|c|c|c|c|c|}
\hline \multicolumn{1}{|c|}{ Wyszczególnienie } & 1992 & 1993 & 1994 & 1995 & 1996 & 1997 & 1998 & 1999 & 2000 \\
\hline Liczba przejęć & 1 & 5 & 12 & 8 & 8 & 6 & 9 & 10 & 4 \\
\hline Liczba fuzji & 0 & 0 & 0 & 0 & 3 & 0 & 1 & 1 & 3 \\
\hline
\end{tabular}

\begin{tabular}{|l|c|c|c|c|c|c|c|c|c|}
\hline \multicolumn{1}{|c|}{ Wyszczególnienie } & 2001 & 2002 & 2003 & 2004 & 2005 & 2006 & 2007 & 2008 & 2009 \\
\hline Liczba przejęć & 6 & 5 & 1 & 2 & 2 & 2 & 3 & 0 & 3 \\
\hline Liczba fuzji & 3 & 0 & 0 & 1 & 0 & 2 & 0 & 1 & 1 \\
\hline
\end{tabular}

\begin{tabular}{|l|c|c|c|c|c|}
\hline \multicolumn{1}{|c|}{ Wyszczególnienie } & 2010 & 2011 & 2012 & 2013 & 2014 \\
\hline Liczba przejęć & 3 & 1 & 3 & 4 & 1 \\
\hline Liczba fuzji & 0 & 1 & 3 & 2 & 1 \\
\hline
\end{tabular}

Źródło: Opracowanie własne.

$\mathrm{W}$ analizie pominięto fuzje przeprowadzone w polskim sektorze bankowym. Wynika to ze specyfiki tych przedsięwzięć. Wszystkie fuzje banków komercyjnych, które nastąpiły po 1989 r., dotyczyły przypadków łączenia podmiotów należących do lub kontrolowanych przez tego samego inwestora strategicznego (fuzje banków krajowych, kontrolowanych przez tego samego inwestora strategicznego lub fuzje banków krajowych ze spółkami córkami inwestorów zagranicznych) i były tylko konsekwencją wcześniejszych przejęć banków komercyjnych. Służyły głównie racjonalizacji ponoszonych kosztów. 


\section{Analiza aktywności inwestorów w fuzjach i przejęciach banków komercyjnych}

Analizie poddano kształtowanie się liczby fuzji i przejęć banków komercyjnych w polskim sektorze bankowym w kontekście:

- dynamiki PKB w Polsce,

- poziomu inflacji,

- wysokości podstawowych stóp procentowych NBP,

- kształtowania się kursu polskiego złotego wobec dolara amerykańskiego, euro oraz marki niemieckiej,

- koniunktury na giełdzie (indeksów giełdowych WIG, WIG20 i WIG-banki),

- opcji politycznej rządzącej krajem (rysunki 1-6).

Rysunek 1. Liczba przejęć w polskim sektorze bankowym w odniesieniu do zmian PKB w Polsce

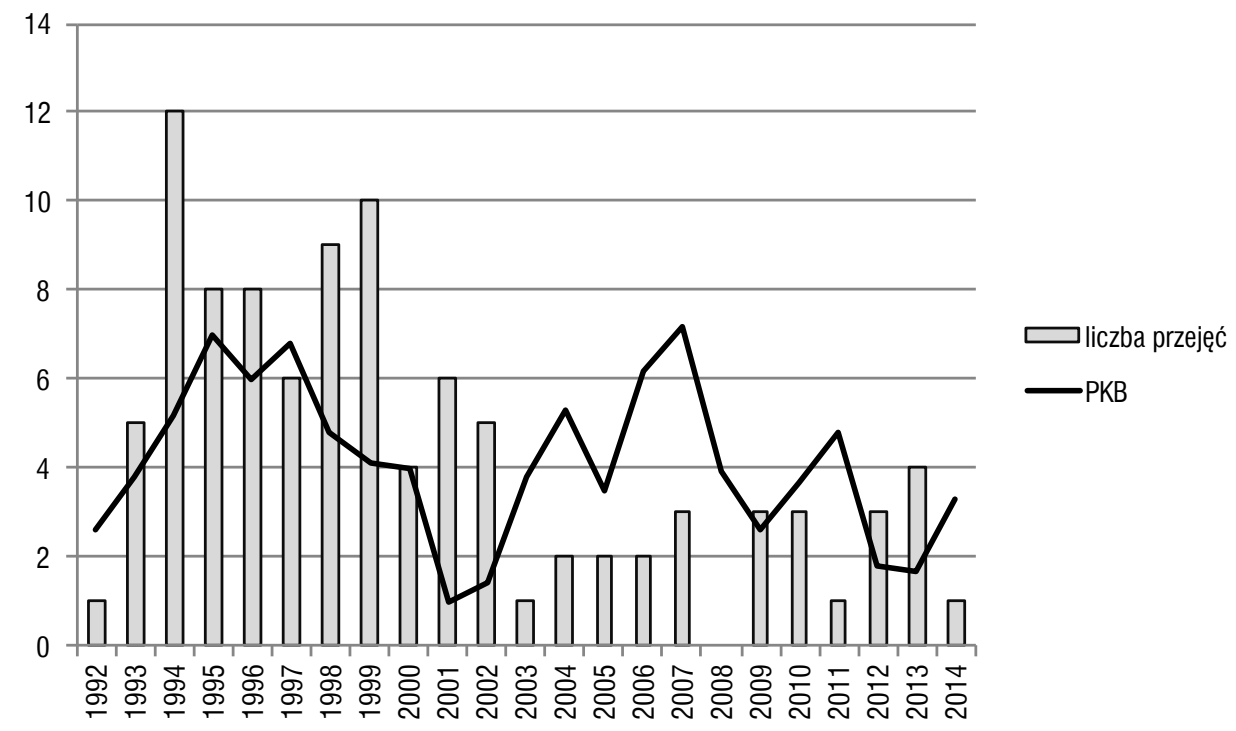

Źródło: Opracowanie własne. 
Rysunek 2. Liczba przejęć w polskim sektorze bankowym w odniesieniu do poziomu inflacji

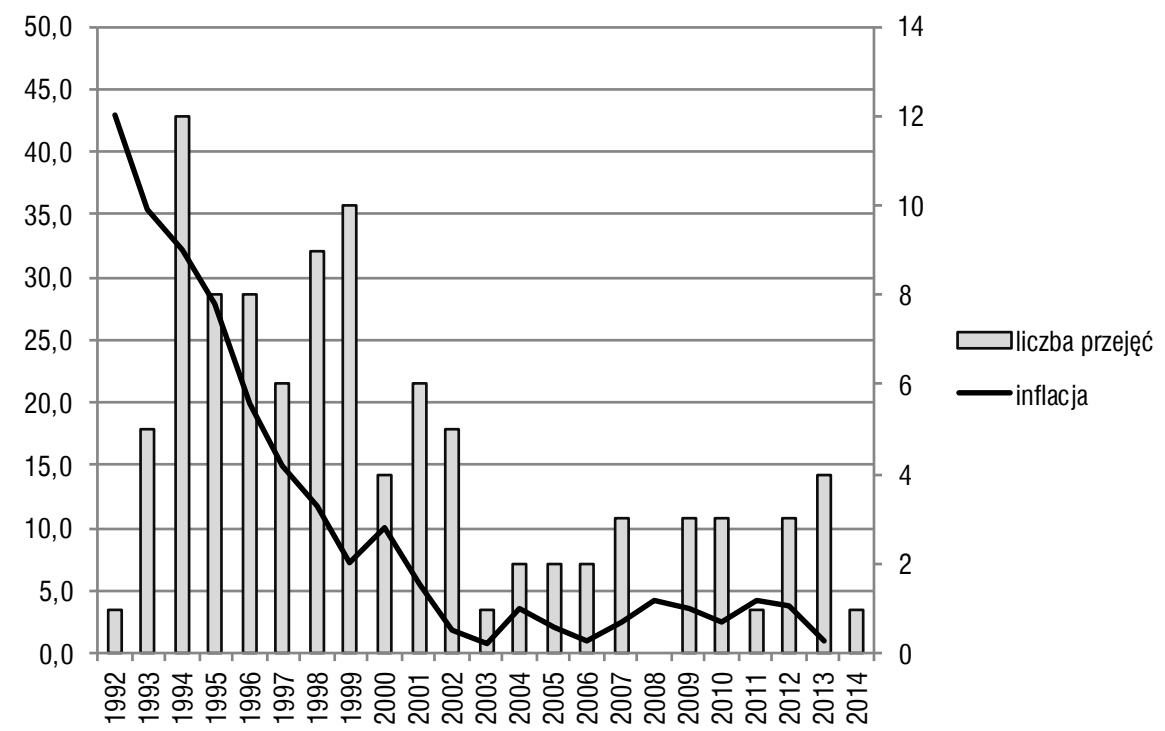

Źródło: Opracowanie własne.

Rysunek 3. Liczba przejęć w odniesieniu do podstawowych stóp procentowych NBP
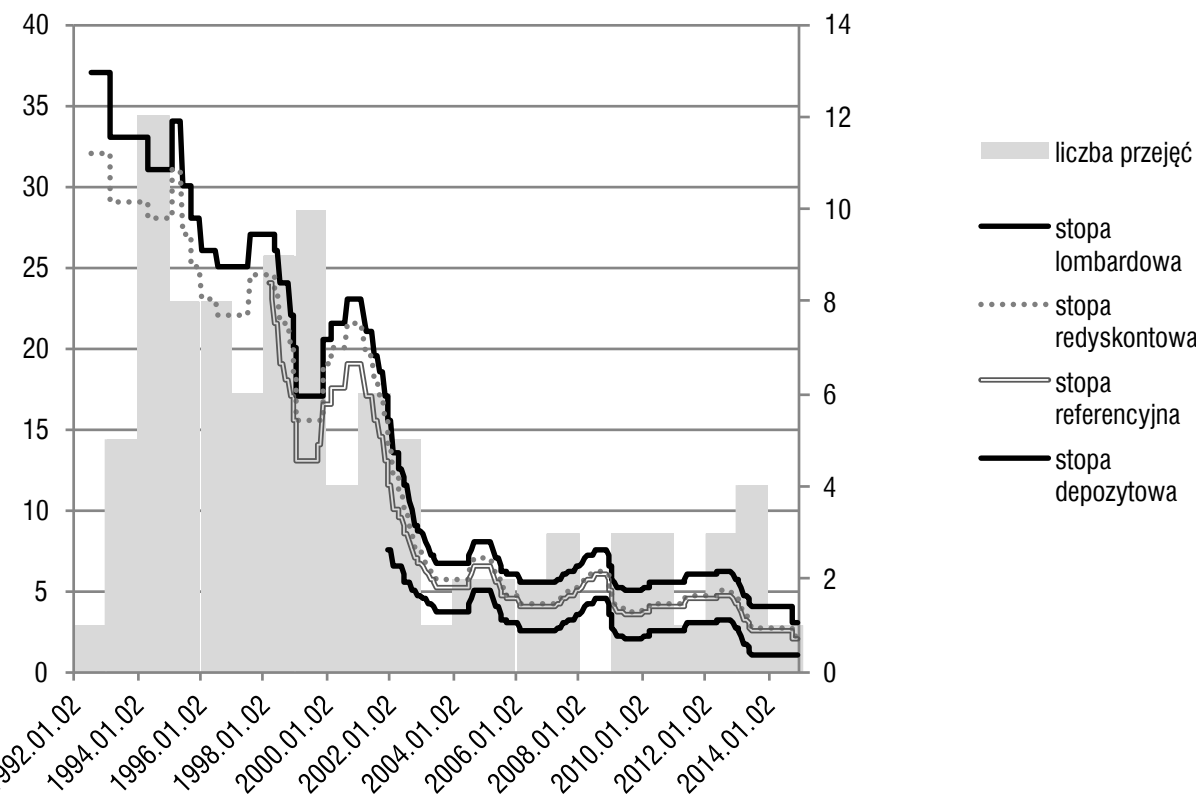

Źródło: Opracowanie własne. 
Rysunek 4. Liczba przejęć w polskim sektorze bankowym w odniesieniu do kształtowania się kursu polskiego złotego wobec dolara amerykańskiego, euro oraz marki niemieckiej

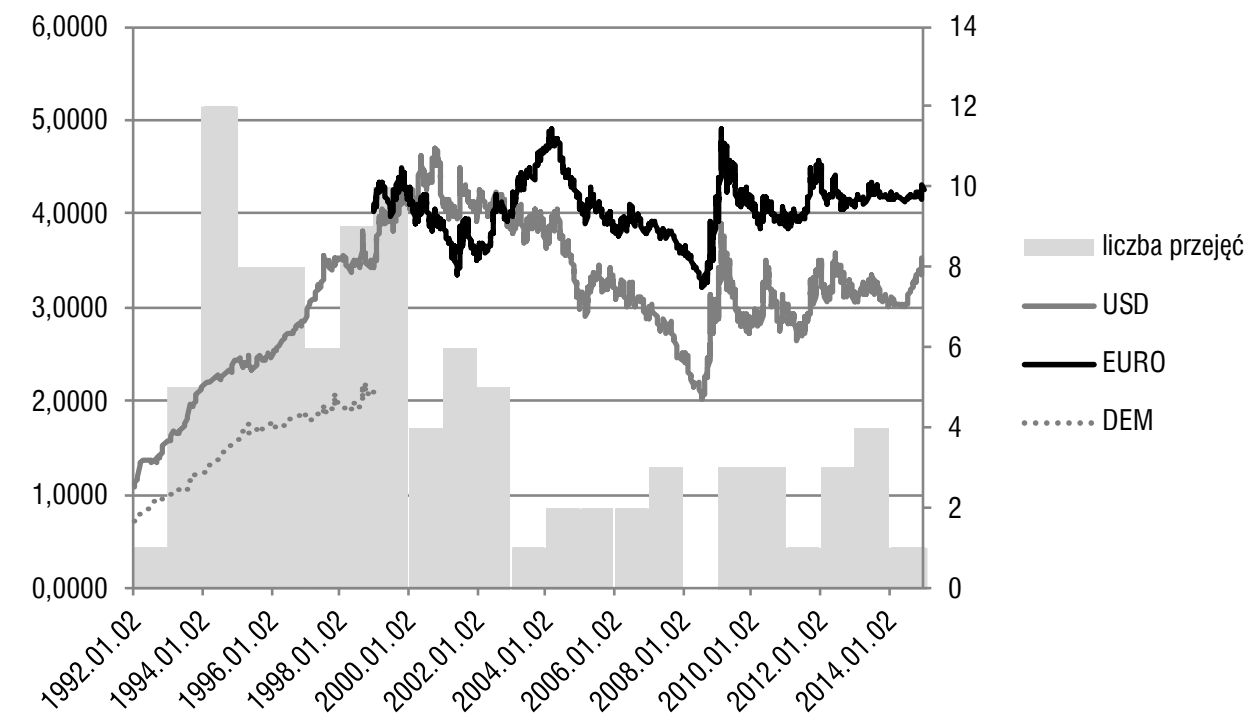

Źródło: Opracowanie własne.

Rysunek 5. Liczba przejęć w polskim sektorze bankowym w odniesieniu do koniunktury na GPW

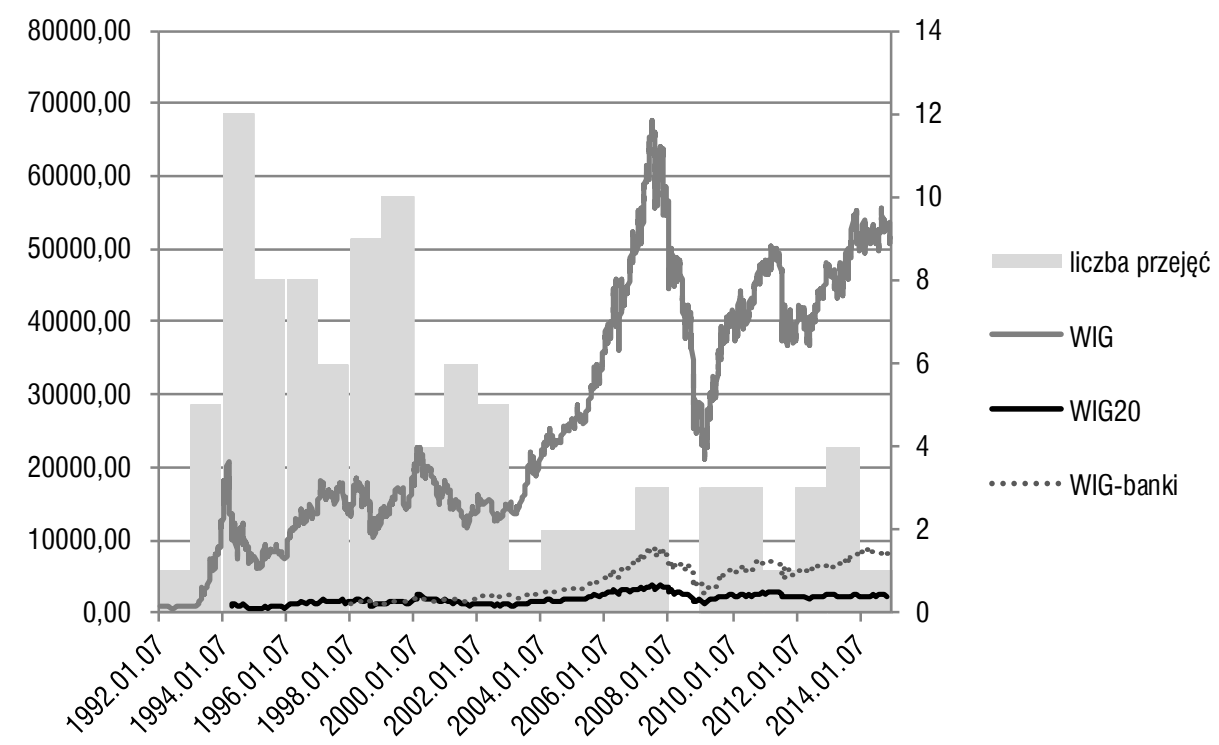

Źródło: Opracowanie własne. 


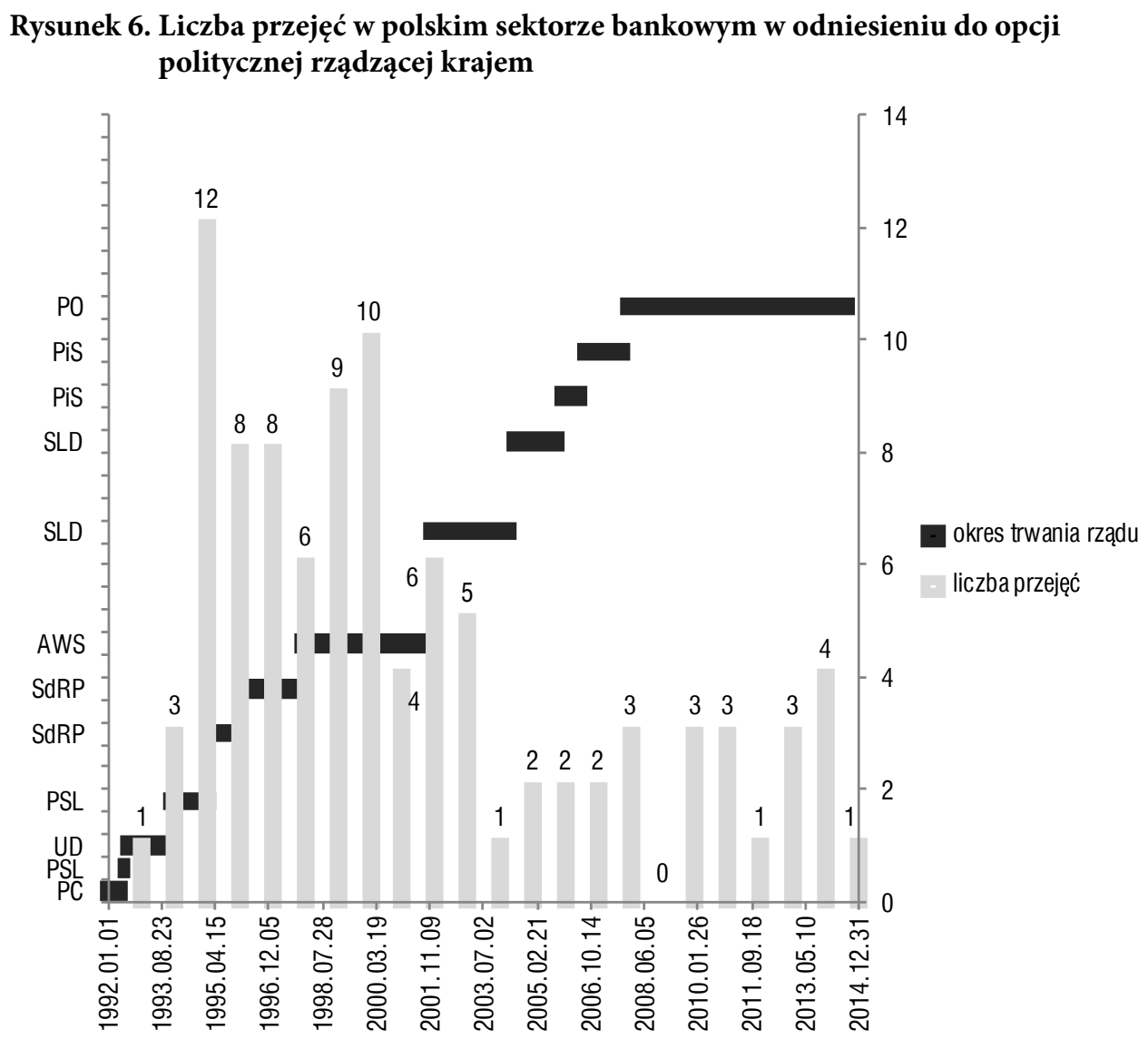

Źródło: Opracowanie własne.

Analiza aktywności inwestorów w procesach fuzji i przejęć banków komercyjnych w polskim sektorze bankowym nie daje jednoznacznych odpowiedzi. Trudno zresztą było spodziewać się innych wyników, zwłaszcza że okres analizy obejmował początkowe lata kształtowania się sektora bankowego po transformacji ustrojowej. Zmiana ustawodawstwa w 1989 r., która stworzyła podstawy dwuszczeblowego systemu bankowego, zapoczątkowała radykalną reformę sektora bankowego. Liberalna polityka w zakresie udzielania licencji na prowadzenie działalności bankowej w początkowym okresie transformacji (wymagana w Polsce minimalna wielkość kapitału założycielskiego wynosiła w 1989 r. 150 tys. PLN i dopiero rok później wysokość ta została zwiększona do $2 \mathrm{mln}$ PLN) oraz nieumiejętne zarządzanie aktywami i pasywami banków komercyjnych przez kadrę zarządzającą, doprowadziły do sytuacji, w której wystąpiły utraty wypłacalności pojedynczych, słabych kapitałowo banków komercyjnych. Na skutek działań interwencyjnych niektóre banki postawione 
zostały w stan upadłości lub likwidacji, a w niektórych wprowadzono zarządy komisaryczne. Sytuacja taka wymusiła relatywnie dużą liczbę fuzji i przejęć w początkowym okresie transformacji ustrojowej.

Rozkład liczby fuzji i przejęć w następnych latach, obok przeobrażeń zachodzących w polskim sektorze bankowym spowodowanych deregulacją i liberalizacją rynku, był determinowany przede wszystkim:

- procesami prywatyzacyjnymi oraz intensywnością polityki prowadzonej przez poszczególne rządy w tym zakresie,

- konsekwencją specyfiki pierwszych przekształceń własnościowych, polegających na pozyskiwaniu strategicznych inwestorów zagranicznych do banków krajowych; procesy konsolidacyjne były więc w pewnym stopniu warunkowane dążeniami głównych akcjonariuszy do osiągnięcia większości w akcjonariacie spółki, - reorientacją prowadzonej strategii przez renomowane, zagraniczne instytucje finansowe w kierunku ekspansji działalności na nowych, wschodzących rynkach usług bankowych w poszukiwaniu potencjalnych możliwości uzyskania wyższych stóp zwrotu w porównaniu z rynkami rozwiniętymi,

- koniecznością restrukturyzacji i sanacji banków w początkowym okresie lat 90. XX w., która była sposobem na ograniczenie rozmiarów kryzysu bankowego.

W latach 1992-2014 trudno dostrzec zauważalną korelację reakcji inwestorów $\mathrm{z}$ analizowanymi czynnikami w badaniu. Jedynym wyraźnym elementem jest kryzys finansowy wywołany kredytami subprime. Upadek Lehman Brothers unaocznil, jak wielkie instytucje finansowe mogą stwarzać realne zagrożenie dla stabilności sektorów bankowych, a nawet gospodarki narodowej poszczególnych państw. Skutkiem swobodnego przepływu kapitału i inwestycji jest bardzo szybkie rozprzestrzenianie się kryzysu z jednego kraju do innych, tzw. efekt zarażania. Jest to zjawisko wielowymiarowe, przebiegające $\mathrm{w}$ sposób dynamiczny, którego następstwem może być efekt domina, czyli proces wywołany przez jedno zdarzenie, uruchamiające łańcuch podobnych wydarzeń, pociągających za sobą określone konsekwencje. Wydarzenia z września i października 2008 r. wpłynęły niewątpliwie na fakt, iż jest to jedyny rok, w którym w całym sektorze nie przeprowadzono żadnej transakcji. Podobne wyniki otrzymano również w zbliżonych badaniach dotyczących przedmiotowego zagadnienia w innych krajach europejskich ${ }^{11}$.

Należy więc uznać, iż brak jest podstaw do sformułowania tezy o cykliczności przeprowadzanych fuzji i przejęć w polskim sektorze bankowym. Rozpatrywany okres jest jednak zbyt niejednorodny i krótki, aby na tej podstawie wysnuwać wnioski co

${ }^{11}$ M. Vancea, Mergers and Acquisitions Waves from the European Union Perspective, "Annals of the University of Oradea" 2013, Economic Science Series, No. 22(2), s. 272-283. 
do tendencji zachodzących w aktywności inwestorów. Ponadto do przeprowadzonej analizy należy podchodzić $\mathrm{z}$ olbrzymią ostrożnością ze względu na relatywnie małą liczbę transakcji.

\section{Podsumowanie}

Dorobek myśli ekonomicznej poświęcony tematyce fuzji i przejęć, w tym także zagadnieniu cykliczności aktywności inwestorów, jest zdominowany przez literaturę i badania, które posługują się danymi z rynków rozwiniętych. Jak wskazuje przeprowadzona analiza, bezpośrednie odnoszenie rezultatów badawczych oraz stworzonych na ich podstawie teoretyczno-metodycznych koncepcji do uwarunkowań i sytuacji panującej w polskim sektorze bankowym, powinno być nacechowane bardzo dużą ostrożnością, ze względu na dysproporcje występujące w rozwoju rynków finansowych oraz w architekturze systemów bankowych i instytucji nadzorczych. Nie zmienia to jednak faktu, iż zrozumienie istoty aktywności inwestorów może przyczynić się do wyjaśnienia mechanizmów procesów konsolidacyjnych, a tym samym uzmysłowić złożoność całego procesu inwestycyjnego w dynamicznie zmieniających się uwarunkowaniach ekonomiczno-społecznych.

\section{Bibliografia}

Andrade G., Mitchell M., Stafford E., New Evidence and Perspectives on Mergers, "Journal of Economic Perspectives" 2001, No. 15(2).

Andrade G., Stafford E., Investigating the Economic Role of Mergers, "Journal of Corporate Finance" 2004, No. 10(1).

Berger A.N., Bonime S.D., Goldberg L.G., White L.J., The Dynamics of Market Entry: The Effects of Mergers and Acquisitions on Entry in the Banking Industry, "Journal of Business" 2004, No. 77(4).

Brealey R.A., Myers S.C., Allen F., Principles of Corporate Finance, Ninth Edition, McGraw-Hill, New York 2008.

Dong M., Hirshleifer D., Richardson S., Teoh S.H., Does Investor Misvaluation Drive the Takeover Market?, "Journal of Finance" 2006, No. 61(2).

Hagendorff J., Collins M., Keasey K., Bank Deregulation and Acquisitions Activity: Cases of the US, Italy and Germany, "Journal of Financial Regulation and Compliance" 2007, No. 15(2). 
Harford J., What Driver Merger Waves?, "Journal of Financial Economics" 2005, No. 77(3). Jovanovic B., Rousseau P., The Q-theory of Mergers, "American Economic Review" 2002, No. 92(2).

Maksimovic V., Phillips G., The Market for Corporate Assets: Who Engages in Mergers and Asset Sales and Are There Efficiency Gains?, "Journal of Finance" 2001, No. 56(6).

Maksimovic V., Phillips G., Yang L., Private and Public Merger Waves, "Journal of Finance" 2013, No. 68(5).

Morellec E., Zhdanov A., The Dynamics of Mergers and Acquisitions, "Journal of Financial Economics" 2005, No. 77(3).

Rhodes-Kropf M., Robinson D. T, Viswanathan S., Valuation Waves and Merger Activity. The Empirical Evidence, "Journal of Financial Economics" 2005, No. 77(3).

Rhodes-Kropf M., Viswanathan S., Market Valuation and Mergers Waves, "Journal of Finance" 2004, No. 59(6).

Shleifer A., Vishny R.W., Stock Market Driven Acquisitions, "Journal of Financial Economics" 2003, No. 70(3).

Vancea M., Mergers and Acquisitions Waves from the European Union Perspective, "Annals of the University of Oradea" 2013, Economic Science Series, No. 22(2).

\section{Activity of Investors During Mergers and Acquisitions in the Polish Banking Sector}

The objective of the study is to analyse periodicity of mergers and acquisitions of commercial banks in the Polish banking sector. The research concentrates on behaviour of strategic investors in this type of investment operations after 1989. The findings of the analysis do not support the thesis about periodicity of mergers and acquisitions in the Polish banking sector. The only element that stands out is the financial crisis caused by subprime credits. There is no doubt that the events of September and October 2008 are responsible for the complete lack of transactions in the sector in that year.

Keywords: commercial banks, mergers and acquisitions, merger waves 


\section{L'activité des investisseurs lors des fusions et des acquisitions dans le secteur bancaire polonais}

L'objectif de l'étude est d'analyser la périodicité des fusions et des acquisitions des banques commerciales dans le secteur bancaire polonais. La recherche se concentre sur le comportement des investisseurs stratégiques dans ce type d'opérations d'investissement après 1989. Les résultats de l'analyse ne confiment pas la thèse sur la périodicité des fusions et acquisitions dans le secteur bancaire polonais. Un seul élément qui se démarque de l'analyse est la crise financière provoquée par les crédits subprimes. Les événements en septembre et octobre 2008 ont conduit à un mangue de transaction dans le secteur bancaire.

Mots-clés: les banques commerciales, les fusions et acquisitions, les vagues des fusions

\section{Активность инвесторов в сфере слияний и поглощений банков в польском банковском секторе}

Цель исследования состоит в анализе периодичности слияний и поглощений коммерческих банков в польском банковском секторе. Исследование охватывает поведение стратегических инвесторов, участвующих в инвестиционных операциях этого типа после 1989 г. Результаты анализа не поддерживают тезис о периодичности проводимых слияний и поглощений в польском банковском секторе. Единственным выделяющимся элементом является финансовый кризис, вызванный субстандартными кредитами. Несомненно, события сентября и октября 2008 года привели к полному отсутствию сделок в секторе в этом году.

Ключевые слова: коммерческие банки, слияния и поглощения, волны слияний и поглощений 